\title{
ANALISIS KOMODITAS UNGGULAN SEKTOR PERTANIAN KECAMATAN SAMIGALUH KABUPATEN KULON PROGO, YOGYAKARTA
}

\author{
Rina Oktavia1*, Ike Yuli Andjani2* \\ * Gadjah Mada University \\ Departemen Ekonomika dan Bisnis, Sekolah Vokasi \\ Jalan Notonegoro, Bulaksumur, Yogyakarta 55281, Indonesia \\ E-mail: rina.oktavia@ugm.ac.id \\ E-mail: ikeyuliandjani@ugm.ac.id
}

\begin{abstract}
Abstrak
Sektor pertanian di Kecamatan Samigaluh adalah mata pencaharian utama penduduk. Sebagian besar penduduk bekerja sebagai petani dengan mengandalkan sawah, kebun dan ladang. Hampir setengah dari tanah yang dimiliki oleh rumah tangga di Kecamatan Samigaluh digunakan untuk lahan pertanian. Berdasarkan penelitian [1], Kecamatan Samigaluh termasuk kategori daerah tertinggal. Oleh karena itu, perlu dilakukan penelitian yang bertujuan untuk mengetahui potensi Kecamatan Samigaluh, terutama sektor pertanian, yang selama ini menjadi mata pencaharian utama penduduk. Diperlukan analisis mengenai komoditas unggulan sektor pertanian di Kabupaten Samigaluh. Hasil penelitian ini diharapkan dapat memberikan petunjuk tentang arah pembangunan Kecamatan Samigaluh, sehingga pembangunan daerah tersebut akan bisa diarahkan ke komoditas-komoditas unggulan yang mampu memberikan kesejahteraan maksimal bagi masyarakat setempat. Metode penelitian yang digunakan dalam penelitian ini adalah metode penelitian kuantitatif menggunakan data sekunder. Alat analisis yang akan digunakan dalam penelitian ini adalah Shift Share Analiysis (SS) dan Location Quotient (LQ). Berdasarkan hasil analisis yang dilakukan, ditemukan bahwa komoditas unggulan sector pertanian di Kecamatan Samigaluh adalah: a) tanaman pangan: padi sawah / ladang; b) tanaman buah: duku / langsat, jeruk siam, salak dan melinjo; c) tanaman obat: mengkudu; d) ternak: kambing; dan e) tanaman perkebunan: kakao, cengkeh dan nilam.
\end{abstract}

Kata kunci: Potensi Daerah, Pembangunan Daerah, Komoditas Unggulan, Analisis Shift Share, and Analisis Location Quotient

\begin{abstract}
The agricultural sector in Samigaluh sub-district is the main livelihood of the population. Most of the population work as farmers by relying on paddy fields, gardens, and fields. Almost half of the land owned by households in Samigaluh sub-district is used for agricultural land. Based on the research of [1], Samigaluh sub-district belongs to the category of underdeveloped areas. Therefore, it is necessary to do a study that aims to find out the potential of Samigaluh sub-district, especially the agricultural sector, which has been the main livelihood of the population. An analysis is needed regarding the leading commodities of the agricultural sector in Samigaluh District. The hope, the results of this study will be able to provide guidance on the direction of development from Samigaluh sub-district so that regional development will be more directed to leading commodities that are able to provide maximum welfare for the population. The research method used in this study is a quantitative research method with secondary data types. The analytical tool that will be used in this study analyzes Shift Share (SS) and Location Quotient (LQ). Based on the results of the analysis carried out, it was found that the leading commodities in Samigaluh sub-ditrict were: a) food crops: rice fields/fields; b) fruit plants: duku / langsat, Siam oranges, salak, and melinjo; c) medicinal plants: noni; d) livestock: goats; and e) plantation crops: cocoa, cloves and patchouli.
\end{abstract}


Keywords: Regional potential, regional development, leading commodities, Shift Share (SS) analysis, and Location Quotient (LQ) analysis

\section{PENDAHULUAN}

Perubahan pada sistem perekonomian Indonesia dari sentralisasi menjadi desentralisasi mendorong masing-masing daerah untuk menggali potensi yang dimiliki. Produk Domestik Regional Bruto (PDRB) merupakan sebuah indikator penting untuk melihat sektor mana saja yang menjadi potensi unggulan dari suatu daerah. Mengetahui potensi unggulan daerah merupakan modal utama pembangunan daerah yang bersangkutan.

Kabupaten Kulon Progo adalah daerah yang memberikan kontribusi terkecil terhadap PDRB Daerah Istimewa Yogyakarta. Kontribusi Kabupaten Kulon Progo selama kurun waktu 2012 - 2016 bahkan lebih kecil dibandingkan dengan Kabupaten Gunung Kidul. Kontribusi terbesar diberikan oleh Kabupaten Sleman, disusul oleh Kota Yogyakarta dan Kabupaten Bantul.

TABEL 1

KONTRIBUSI TERHADAP JUMLAH PDRB HARGA BERLAKU SELURUH KABUPATEN/KOTA DI DAERAH ISTIMEWA YOGYAKARTA, 2012 - 2016 (PERSEN)

\begin{tabular}{|l|r|r|r|r|r|}
\hline Kabupaten/Kota & 2012 & \multicolumn{1}{|c|}{2013} & 2014 & $\begin{array}{c}2015 \\
*\end{array}$ & $2016 * *$ \\
\hline Kulon Progo & 7,66 & 7,64 & 7,60 & 7,56 & 7,55 \\
\hline Bantul & 18,79 & 18,99 & 19,04 & 19,06 & 19,00 \\
\hline Gunung Kidul & 13,65 & 13,57 & 13,52 & 13,61 & 13,60 \\
\hline Sleman & 33,31 & 33,29 & 33,28 & 33,35 & 33,59 \\
\hline Yogyakarta & 26,59 & 26,52 & 26,56 & 26,42 & 26,26 \\
\hline DIY & 100 & 100 & 100 & 100 & 100 \\
\hline
\end{tabular}

Sumber: Data Strategis Daerah Istimewa Yogyakarta

**: Angka Sangat Sementara

Kecamatan Samigaluh merupakan salah satu kecamatan berupa dataran tinggi/perbukitan menoreh yang terletak di Kabupaten Kulon Progo, Provinsi Daerah Istimewa Yogyakarta. Luas Kecamatan Samigaluh 6.929,31 ha $(69,29 \mathrm{~km} 2)$, menduduki peringkat kedua kecamatan terluas di Kabupaten Kulon Progo dengan persentase 11, 82 persen dari luas Kabupaten Kulon Progo secara keseluruhan. Hampir setengah dari luas lahan yang dikuasai rumah tangga di Kecamatan Samigaluh digunakan untuk lahan pertanian. Maka dari itu, sector pertanian di Kecamatan Samigaluh menjadi mata pencaharian utama penduduk setempat. Sebagian besar penduduk setempat bekerja sebagai petani dengan mengandalkan lahan sawah, kebun dan ladang/tegalan.

Namun, berdasarkan penelitian [1], Kecamatan Samigaluh termasuk dalam daerah tertinggal. Ini menandakan bahwa kinerja perekonomian di Kecamatan Samigaluh belum maksimal. Maka dari itu, perlu dilakukan sebuah penelitian yang bertujuan untuk mengetahui potensi yang dimiliki oleh Kecamatan Samigaluh khususnya sector pertanian yang selama ini menjadi mata pencaharian utama penduduk. Diperlukan sebuah analisis terkait komoditas unggulan sector pertanian di Kecamatan Samigaluh. Harapannya, hasil penelitian ini Akan dapat memberikan petunjuk arah pembangunan dari Kecamatan Samigaluh sehingga pembangunan daerah tersebut Akan bisa lebih diarahkan kepada komoditas-komoditas unggulan yang mampu memberikan kesejahteraan sebesar-besarnya bagi masyarakat setempat.

Berdasarkan latar belakang di atas, rumusan masalah yang diangkat dalam penelitian ini adalah apa komoditas unggulan sector pertanian Kecamatan Samigaluh Kabupaten Kulon Progo? Sedangkan tujuan penelitian ini adalah untuk mengetahui komoditas - komoditas unggulan yang dimiliki oleh sector pertanian di Kecamatan Samigaluh, Kabupaten Kulon Progo.

\section{TINJAUAN PUSTAKA}

Pembangunan ekonomi daerah menurut [2] adalah suatu proses dimana pemerintah daerah dan seluruh komponen masyarakat mengelola sumberdaya yang dimiliki dan membentuk suatu pola kemitraan untuk menciptakan lapangan kerja baru serta merangsang perkembangan kegiatan ekonomi di daerah tersebut.

Sektor unggulan adalah sebuah sektor yang berperan besar terhadap perkembangan perekonomian suatu daerah karena mempunyai keunggulan - keunggulan / kriteria. Menurut [3], terdapat tiga kriteria sebuah sektor dikatakan sebagai sector unggulan, yaitu:

1. Sektor tersebut memiliki laju pertumbuhan ekonomi yang tinggi;

2. Sektor tersebut memiliki angka penyerapan tenaga kerja yang relatif besar; dan

3. Sektor tersebut memiliki keterkaitan antara sector yang tinggi baik ke depan maupun ke belakang, sektor yang mampu menciptakan nilai tambah yang tinggi.

Pemikiran J.S. Mill menjadi dasar dari teori basis yang mengatakan bahwa untuk memecahkan masalah pertumbuhan dan pemerataan regional diisyaratkan adanya perdagangan antar daerah dengan mewujudkan spesialisasi daerah. Menurut [4], teori basis ekonomi berdasarkan pada pandangan bahwa laju pertumbuhan ekonomi suatu wilayah ditentukan oleh besar kecilnya ekspor dari wilayah tersebut. Perekonomian regional dapat dibagi menjadi dua 
sektor, yaitu sektor basis dan non-basis. Sektor basis adalah sektor yang mengekspor barang dan jasa ke tempat-tempat di luar batas-batas perekonomian daerah yang bersangkutan. Sedangkan sektor non-basis adalah sektor yang tidak mengekspor, yakni hanya sebatas untuk memenuhi kebutuhan di dalam daerah tersebut.

Sementara itu, menurut [5], dasar pemikiran teori basis adalah karena industri basis menghasilkan barang dan jasa baik untuk pasar di dalam maupun di luar daerah. Adanya penjualan barang dan jasa keluar daerah tersebut, selanjutnya Akan mampu mendatangkan arus pendapatan kedalam daerah tersebut. Arus pendapatan ini menyebabkan baik kenaikan konsumsi maupun investasi di daerah tersebut, yang pada gilirannya Akan menaikan pendapatan dan kesempatan kerja. Jika di daerah tersebut terdapat banyak pengangguran, maka kesempatan kerja yang baru tersebut akan mampu menampungnya, atau jika di daerah tersebut tidak terdapat pengangguran, maka daerah tersebut akan mempunyai daya tarik bagi orang-orang dari luar daerah untuk mencari pekerjaan di daerah tersebut. Kenaikan pendapatan yang terjadi, tidak hanya menaikkan permintaan terhadap hasil industri basis, tetapi juga Akan menaikkan permintaan hasil industri lokal non basis. Selanjutnya, kenaikan permintaan tersebut Akan menaikkan investasi di industri-industri non-basis.

Bertambah banyaknya sektor basis di suatu daerah Akan meningkatkan arus pendapatan ke daerah yang bersangkutan, menambah permintaan terhadap barang dan jasa, meningkatkan nilai investasi dan menimbulkan kenaikan volume kegiatan bukan basis. Dengan demikian, sesuai dengan namanya, sektor basis mempunyai peran sebagai penggerak pertama dimana setiap perubahan mempunyai efek multiplier terhadap perekonomian agregat. Berdasarkan gagasan inilah, maka para ahli berpendapat bahwa sektor-sektor basis inilah yang seharusnya dikembangkan di suatu daerah.

Setelah adanya otonomi daerah, tiap-tiap daerah menjadi lebih bebas untuk menentukan sector / komoditi yang diprioritaskan pengembangannya. Maka dari itu, mengenali potensi yang dimiliki adalah hal yang sangat penting bagi suatu daerah. Hal ini diperlukan untuk menentukan sektor-sektor riil yang perlu dikembangkan agar perekonomian daerah tersebut tumbuh cepat dan di sisi lain untuk mengidentifikasi faktor-faktor yang membuat potensi sektor tersebut rendah sehingga dapat ditentukan prioritas kebijakan untuk menanggulangi masalah tersebut [6].

Keunggulan komparatif (comparative advantage) adalah suatu kegiatan ekonomi yang menurut perbandingan lebih menguntungkan bagi pengembangan daerah. Keunggulan komparatif dapat digunakan untuk melihat suatu komoditi memiliki prospek untuk dikembangkan atau tidak. Dalam perdagangan bebas antardaerah, mekanisme pasar mendorong masing-masing daerah untuk melakukan spesialisasi perdagangan pada sektor dimana daerahnya memiliki keunggulan komparatif. Pengetahuan terhadap keunggulan komparatif suatu daerah dapat digunakan oleh para penentu kebijakan untuk mendorong struktur perekonomian daerah ke arah sektor yang memiliki keunggulan komparatif. Jadi, jika suatu sektor memiliki keunggulan komparatif bagi suatu daerah, maka pembangunan sector tersebut dapat lebih diprioritaskan daripada sektor yang lainnya [6].

[7] melakukan penelitian serupa terkait Analisis Potensi Kecamatan Berbasis Komoditas Pertanian dalam Pembangunan Wilayah di Kabupaten Sleman. Berdasarkan hasil penelitiannya tersebut diketahui bahwa semua komoditas pertanian menjadi komoditas basis di berbagai kecamatan sesuai dengan potensi karakteristik wilayah kecamatan yang cocok dengan jenis komoditas pertaniannya.

\section{METODE PENELITIAN}

Pendekatan penelitian yang digunakan dalam penelitian ini adalah pendekatan penelitian kuantitatif. Pendekatan kuantitatif menitikberatkan pada pengujian data-data dimana pembahasan dalam penelitian ini tergantung hasil yang ditunjukkan dari estimasi data-data yang digunakan. Data yang digunakan dalam penelitian ini adalah data sekunder. Teknik pengumpulan data yang digunakan dalam penelitian ini adalah studi dokumenter, yakni dengan melakukan pengumpulan dan pencatatan data yang terdapat dalam laporan Statistik Kabupaten Kulon Progo dalam Angka, Kecamatan Samigaluh dalam Angka, Potret Potensi Ekonomi Kulon Progo (Analisis Hasil SE 2016 Listing), dan lain-lain.

Alat analisis yang digunakan untuk menjawab rumusan masalah dalam penelitian ini adalah analisis Shift Share (SS) dan Location Quotient (LQ). Analisis shift share adalah teknik analisis kuantitatif yang biasa digunakan untuk menganalisis perubahan struktur ekonomi daerah relatif terhadap struktur ekonomi wilayah administratif yang lebih tinggi sebagai pembanding. Analisis shift share dapat mengetahui sektor-sektor ekonomi unggulan dari suatu wilayah (misal: desa, kecamatan, kabupaten atau provinsi) dan perbandingan relative tingkat pertumbuhan perekononomian wilayah serta kecenderungannya. Hasil analisis ini dapat menjelaskan kinerja (performance) suatu aktivitas di suatu wilayah serta mampu menggambarkan sebab-sebab terjadinya pertumbuhan suatu aktivitas. Sebab-sebab terjadinya pertumbuhan suatu aktivitas antara lain: 1). Sebab yang berasal dari dinamika local (sub wilayah); 2). Sebab dari dinamika 
aktivitas/sektor (total wilayah); dan 3). Sebab dari dinamika wilayah secara umum.

Analisis Location Quotient (LQ) menurut [8] digunakan untuk menentukan sektor unggulan dari suatu daerah. Hal ini dapat diketahui dengan membuat perbandingan relatif antara kemampuan sektor di daerah yang diamati dengan kemampuan sektor yang sama pada daerah di tingkat atasnya pada kurun waktu tertentu. Menurut [9], Location Quotient (LQ) adalah suatu alat untuk mengidentifikasi sektor/komoditas unggulan daerah yang lebih sederhana dengan segala kelebihan dan keterbatasannya. Analisis Location Quotient $(L Q)$ merupakan salah satu pendekatan yang umum digunakan dalam model ekonomi basis sebagai sebuah langkah awal untuk memahami sektor yang menjadi pemacu pertumbuhan suatu daerah. Jenis analisis ini mengukur konsentrasi relative atau derajat spesialisasi kegiatan ekonomi melalui pendekatan perbandingan.

Inti dari model ekonomi basis adalah arah dan pertumbuhan suatu wilayah ditentukan oleh ekspor wilayah tersebut. Teori ekonomi basis mengklasifikasikan seluruh kegiatan ekonomi ke dalam dua sektor, yaitu sektor basis dan non basis. Sektor ekonomi basis yaitu sektor di suatu daerah yang hasilnya baik berupa barang maupun jasa ditujukan untuk ekspor ke luar daerah tersebut. Sedangkan kegiatan non basis yaitu sektor di suatu daerah yang hasilnya baik berupa barang maupun jasa ditujukan untuk masyarakat daerah itu sendiri.

Menurut [10], analisis Location Quotient (LQ) dinyatakan melaui persamaan matematis:

$$
L Q=\frac{R_{i} / R_{t}}{N_{i} / N_{t}}
$$

Keterangan:

Ri: Produksi sektor pertanian di Kecamatan Samigaluh

Rt: Total produksi sektor pertanian di Kecamatan Samigaluh

Ni: Produksi sektor pertanian di Kabupaten Kulon Progo

Nt: Total Produksi sektor pertanian di Kabupaten Kulon Progo

Keterangan:

$\mathrm{LQ}<1$ : berarti sektor yang bersangkutan produksinya belum dapat memenuhi kebutuhan daerah sendiri, disebabkan oleh kurangnya peranan sektor tersebut dalam perekonomian daerah karena tidak mempunyai keunggulan komparatif dan dikategorikan sektor non basis.

LQ > $1 /$ LQ = 1 : berarti sektor yang bersangkutan produksinya sudah dapat memenuhi kebutuhan daerah tersebut bahkan mengekspor. Oleh karena itu daerah tersebut dikatakan mempunyai keunggulan komparatif di sektor tersebut dan dikatakan sebagai sektor basis.

\section{HASIL DAN PEMBAHASAN}

Sektor pertanian terdiri dari 6 subsektor, yaitu subsektor pertanian tanaman pangan, pertanian tanaman hortikultura, perkebunan, peternakan, perikanan, dan kehutanan. Pada penelitian hanya Akan dibahas subsector pertanian tanaman pangan, pertanian tanaman hortikultura, perkebunan, dan peternakan. Komoditas subsektor tanaman pangan antara lain: padi sawah/ladang, jagung, ketela pohon, dan kacang tanah. Subsector tanaman hortikultura terdiri dari tanaman buah dan tanaman obat. Komoditas subsektor tanaman hortikultura buah antara lain: alpokat, mangga, rambutan, duku, jeruk besar, jeruk siam, sirsak, durian, jambu, sukun, sawo, pepaya, pisang, nanas, salak, nangka, mlinjo, dan petai. Sementara komoditas subsektor tanaman hortikultura obat antara lain: jahe, Laos, kencur, kunyit, dan mengkudu. Komoditas subsektor peternakan antara lain: sapi, kerbau, kambing, domba, ayam buras, itik, dan kelinci.

\section{Subsektor Pertanian Tanaman Pangan}

Hasil Analisis Location Question (LQ) Subsektor Pertanian Tanaman Pangan

Berdasarkan hasil analisis Location Question (LQ) pada subsector pertanian tanaman pangan di Kecamatan Samigaluh, diketahui bahwa padi sawah/ladang memiliki nilai LQ>1, yaitu sebesar 1, 38. Hal ini menunjukan bahwa hasil komoditas dari padi sawah/ladang dapat mencukupi kebutuhan di Kecamatan Samigaluh dan di wilayah lainnya. Sedangkan untuk komoditas jagung, ketela pohon dan kacang tanah memiliki nilai $\mathrm{LQ}<1$. Komoditas jagung memiliki nilai LQ sebesar 0, 73, ketela pohon sebesar 0, 30 dan kacang tanah sebesar 0, 68. Hal itu menunjukkan bahwa komoditas-komoditas tersebut termasuk komoditas yang tidak unggul di Kecamatan Samigaluh. Dengan demikian, komoditas jagung, ketela pohon dan kacang tanah belum mampu untuk memenuhi kebutuhan di Kecamatan Samigaluh dan wilayah lainnya.

TABEL 2

HASIL ANALISIS LOCATION QUESTION (LQ) SUBSECTOR PERTANIAN TANAMAN PANGAN

\begin{tabular}{|l|r|r|c|}
\hline \multirow{2}{*}{ Jenis Komoditas } & \multicolumn{2}{|c|}{ Produksi (ton) } & \multirow{2}{*}{ LQ } \\
\cline { 2 - 3 } & $\begin{array}{c}\text { Kecamatan } \\
\text { Samigaluh }\end{array}$ & $\begin{array}{c}\text { Kabupaten } \\
\text { Kulon Progo }\end{array}$ & \\
\hline Padi sawah / ladang & 43416.3 & 720941.8 & 1.38578 \\
\hline Jagung & 5367.25 & 168870.1 & 0.73138 \\
\hline Ketela pohon & 4302.7 & 329448 & 0.30054 \\
\hline Kacang tanah & 221.3 & 7419.7 & 0.68634 \\
\hline Jumlah & 53307.55 & 1226679.6 & \\
\hline
\end{tabular}

Sumber: Hasil Analisis, 2018 
Hasil Analisis Shift Share (SS) Subsektor Pertanian Tanaman Pangan

Berdasarkan hasil analisis Shift Share (SS) pada subsector pertanian tanaman pangan di Kecamatan Samigaluh, diketahui bahwa komoditas padi sawah/ladang dan jagung memiliki nilai positif (+), dimana komoditas padi sawah/ladang memiliki nilai sebesar 2010, 46 dan jagung sebesar 1756, 17. Sehingga pertumbuhan pada komoditas tersebut dapat memicu pertumbuhan pada sektor tanaman pangan karena memiliki pertumbuhan yang cepat. Sedangkan komoditas ketela pohon dan kacang tanah memiliki nilai negatif (-), dimana komoditas ketela pohon memiliki nilai sebesar $-318,13$ dan kacang tanah sebesar -8,722. Sehingga perkembangan dari komoditas tersebut tidak dapat memicu pertumbuhan pada sektor tanaman pangankarena memiliki pertumbuhan yang lambat.

TABEL 3

HASIL ANALISIS SHIFT SHARE ANALYSIS (SS) SUBSECTOR PERTANIAN TANAMAN PANGAN

\begin{tabular}{|l|r|r|c|}
\hline \multirow{2}{*}{ Jenis Komoditas } & \multicolumn{2}{|c|}{ Produksi (ton) } & \multirow{2}{*}{ SS } \\
\cline { 2 - 3 } & $\begin{array}{l}\text { Kecamatan } \\
\text { Samigaluh }\end{array}$ & $\begin{array}{c}\text { Kabupaten } \\
\text { KulonProgo }\end{array}$ & \\
\hline Padi sawah / ladang & 43416.3 & 720941.8 & 2010.46 \\
\hline Jagung & 5367.25 & 168870.1 & 1756.17 \\
\hline Ketela Pohon & 4302.7 & 329448 & -318.13 \\
\hline Kacang Tanah & 221.3 & 7419.7 & -8.7229 \\
\hline Jumlah & 53307.55 & 1226679.6 & \\
\hline
\end{tabular}

Sumber: Hasil Analisis, 2018

Komoditas Unggulan Sub-sektor Tanaman Pangan Berdasarkan hasil analisis Location Question (LQ) dan Shift Share (SS) dapat disimpulkan bahwa komoditas padi sawah/ladang merupakan komoditas unggulan di Kecamatan Samigaluh. Hal ini dikarenakan padi sawah/ladang memiliki nilai LQ > 1 dan nilai positif (+), yang artinya komoditas padi sawah/ladang dapat mencukupi kebutuhan di Kecamatan Samigaluh dan dapat menjadi pemicu pertumbuhan di subsektor tanaman pangan Kecamatan Samigaluh. Berbeda dengan komoditas lainnya, komoditas jagung dapat memicu pertumbuhan pada subsektor tanaman pangan tetapi belum mampu untuk mencukupi kebutuhan di Kecamatan Samigaluh dan wilayah sekitarnya. Sedangkan ketela pohon dan kacang tanah merupakan komoditas yang tidak unggul, karena komoditas tersebut selain tidak mampu mencukupi kebutuhan Kecamatan Samigaluh, komoditas tersebut juga tidak memicu pertumbuhan tanaman pangan lainnya.

TABEL 4

KOMODITAS UNGGULAN

SUB-SEKTOR PERTANIAN TANAMAN PANGAN

\begin{tabular}{|l|c|c|c|}
\hline Jenis Komoditas & LQ & SS & Kesimpulan \\
\hline
\end{tabular}

\begin{tabular}{|l|c|r|r|}
\hline \multicolumn{1}{|c|}{ Jenis Komoditas } & LQ & SS & Kesimpulan \\
\hline Padi sawah / ladang & 1.385782 & 2010.4638 & Unggulan \\
\hline Jagung & 0.731377 & 1756.1672 & Tidak unggul \\
\hline Ketela pohon & 0.300536 & -318.13414 & Tidak unggul \\
\hline Kacang tanah & 0.686337 & -8.722999 & Tidak unggul \\
\hline
\end{tabular}

Sumber: Hasil Analisis, 2018

Subsektor Pertanian Tanaman Hortikultura Buah Hasil Analisis Location Question (LQ) Subsektor Pertanian Tanaman Hortikultura Buah

Berdasarkan hasil analisis Location Question (LQ) pada subsector pertanian tanaman hortikultura buah, diketahui bahwa sebagian besar komoditas buah memiliki nilai LQ>1, yaitu sebanyak 11 komoditas. Dimana komoditas tersebut yaitu memiliki nilai LQ sebesar 3,14 untuk komoditas alpukat, sebesar 1,20 untuk komoditas rambutan, sebesar 7,06 untuk komoditas duku/langsat, sebesar 5,61 untuk komoditas jeruk besar, sebesar 1,22 untuk komoditas jeruk siam, sebesar 1,46 untuk komoditas sukun, sebesar 1,06 untuk komoditas pepaya, sebesar 2,64 untuk komoditas salak, sebesar 1,16 untuk komoditas nangka, sebesar 1,35 untuk komoditas melinjo dan sebesar 2,07 untuk komoditas petai. Hal ini menunjukan bahwa hasil komoditas dari buah-buahan tersebut dapat mencukupi kebutuhan di Kecamatan Samigaluh dan di wilayah lainnya.

Sedangkan untuk komoditas yang memiliki nilai LQ<1, yaitu sebanyak 7 komoditas. Dimana komoditas tersebut mimiliki nilai LQ sebesar 0,48 untuk komoditas mangga, sebesar 0,22 untuk komoditas sirsak, sebesar 0,95 untuk komoditas durian, sebesar 0,13 untuk komoditas jambu, sebesar 0,89 untuk komoditas sawo, sebesar 0,31 untuk komoditas pisang dan sebesar 0,39 untuk komoditas nanas. Hal tersebut menunjukkan bahwa komoditas mangga, sirsak, durian, jambu, sawo, pisang dan nanas belum mampu untuk mencukupi kebutuhan di Kecamatan Samigaluh dan wilayah lain.

$$
\text { TABEL } 5
$$

HASIL ANALISIS LOCATION QUESTION (LQ) SUBSEKTOR PERTANIAN TANAMAN HORTIKULTURA BUAH

\begin{tabular}{|l|r|r|r|}
\hline \multirow{2}{*}{ Jenis Komoditas } & \multicolumn{2}{|c|}{ Produksi (kwintal) } & \multirow{2}{*}{ LQ } \\
\cline { 2 - 3 } & $\begin{array}{c}\text { Kecamatan } \\
\text { Samigaluh }\end{array}$ & $\begin{array}{c}\text { Kabupaten } \\
\text { Kulon Progo }\end{array}$ & \\
\hline Alpokat & 19311 & 60126 & 3.1446 \\
\hline Mangga & 25009 & 510000 & 0.4801 \\
\hline Rambutan & 34115 & 256223 & 1.3036 \\
\hline Duku/Langsat & 28020 & 38829 & 7.0654 \\
\hline JerukBesar & 9073 & 15818 & 5.616 \\
\hline Jeruk Siam & 10630 & 84881 & 1.2262 \\
\hline Sirsak & 201 & 8673 & 0.2269 \\
\hline Durian & 22242 & 226952 & 0.9595 \\
\hline Jambu & 1096 & 76659 & 0.14 \\
\hline
\end{tabular}




\begin{tabular}{|l|r|r|r|}
\hline \multirow{2}{*}{ Jenis Komoditas } & \multicolumn{2}{|c|}{ Produksi (kwintal) } & \multirow{2}{*}{ LQ } \\
\cline { 2 - 3 } & $\begin{array}{c}\text { Kecamatan } \\
\text { Samigaluh }\end{array}$ & $\begin{array}{c}\text { Kabupaten } \\
\text { Kulon Progo }\end{array}$ & \\
\hline Sukun & 33329 & 222744 & 1.4650 \\
\hline Sawo & 4933 & 53698 & 0.8995 \\
\hline Pepaya & 16892 & 155070 & 1.0665 \\
\hline Pisang & 32753 & 1032603 & 0.3106 \\
\hline Nanas & 680 & 16878 & 0.3945 \\
\hline Salak & 23570 & 87172 & 2.6473 \\
\hline Nangka & 35799 & 302003 & 1.1606 \\
\hline Melinjo & 48046 & 346951 & 1.3559 \\
\hline Petai & 21764 & 102535 & 2.0782 \\
\hline Jumlah & 367463 & 3597815 & \\
\hline
\end{tabular}

Sumber: Hasil Analisis, 2018

Hasil Analisis Shift Share (SS) Subsektor Pertanian Tanaman Hortikultura Buah

Berdasarkan hasil analisis Shift Share (SS) pada subsector pertanian tanaman hortikultura buah, diketahui bahwa komoditas tanaman buah yang memiliki nilai Shift Share positif (+) dan negatif (-) adalah seimbang. Beberapa komoditas yang memiliki nilai Shift Share positif (+) yaitu komoditas duku/langsat dengan nilai sebesar 356,73, komoditas jeruk siam sebesar 102,17, komoditas sirsak sebesar 6,49, komoditas durian sebesar 199,12, komoditas jambu sebesar 178,40, komoditas sawo sebesar 40,87, komoditas pisang sebesar 349,73, komoditas salak sebesar 2997,64 dan komoditas melinjo sebesar 155,31. Hal itu menunjukkan bahwa komoditas tersebut memiliki pertumbuhan yang cepat sehingga dapat memicu pertumbuhan tanaman buah lainnya.

Namun masih terdapat beberapa komoditas yang memiliki nilai perhitungan Shift Share yang bernilai negatif (-) yaitu komoditas alpokat, mangga, rambutan, jeruk besar, sukun, pepaya, nanas, nangka, dan petai. Dimana alpokat memiliki nilai SS sebesar -1984,16, mangga sebesar -1825,96, rambutan sebesar $-1682,09$, jeruk besar yaitu $-128,16$, sukun yaitu $-39,31$, pepaya yaitu $-874,51$, nanas yaitu $-35,04$, nangka yaitu $-883,86$, dan patai yaitu -149659 . Sehingga perkembangan dari komoditas tersebut tidak dapat memicu pertumbuhan pada sektor tanaman buah karena memiliki pertumbuhan yang lambat.

TABEL 6

HASIL ANALISIS SHIFT SHARE (SS) SUBSEKTOR PERTANIAN TANAMAN HORTIKULTURA BUAH

\begin{tabular}{|l|r|r|c|}
\hline \multirow{2}{*}{$\begin{array}{c}\text { Jenis } \\
\text { Komoditas }\end{array}$} & \multicolumn{2}{|c|}{ Produksi (ton) } & \multirow{2}{*}{ SS } \\
\cline { 2 - 3 } & $\begin{array}{c}\text { Kecamatan } \\
\text { Samigaluh }\end{array}$ & $\begin{array}{c}\text { Kabupaten } \\
\text { Kulon Progo }\end{array}$ & \\
\hline Alpokat & 19311 & 60126 & -1984.17 \\
\hline Mangga & 25009 & 510000 & -1825.96 \\
\hline Rambutan & 34115 & 256223 & -1692.09 \\
\hline
\end{tabular}

\begin{tabular}{|l|r|r|r|}
\hline \multirow{2}{*}{$\begin{array}{c}\text { Jenis } \\
\text { Komoditas }\end{array}$} & \multicolumn{2}{|c|}{ Produksi (ton) } & \multirow{2}{*}{ SS } \\
\cline { 2 - 3 } & $\begin{array}{r}\text { Kecamatan } \\
\text { Samigaluh }\end{array}$ & $\begin{array}{c}\text { Kabupaten } \\
\text { Kulon Progo }\end{array}$ & \\
\hline Duku / Langsat & 28020 & 38829 & 356.738 \\
\hline Jeruk Besar & 9073 & 15818 & -128.169 \\
\hline Jeruk Siam & 10630 & 84881 & 102.179 \\
\hline Sirsak & 201 & 8673 & 6.49312 \\
\hline Durian & 22242 & 226952 & 199.129 \\
\hline Jambu & 1096 & 76659 & 178.405 \\
\hline Sukun & 33329 & 222744 & -39.317 \\
\hline Sawo & 4933 & 53698 & 40.8741 \\
\hline Pepaya & 16892 & 155070 & -874.519 \\
\hline Pisang & 32753 & 1032603 & 349.730 \\
\hline Nanas & 680 & 16878 & -35.0469 \\
\hline Salak & 23570 & 87172 & 2997.642 \\
\hline Nangka & 35799 & 302003 & -883.863 \\
\hline Melinjo & 48046 & 346951 & 155.317 \\
\hline Petai & 21764 & 102535 & -1496.591 \\
\hline Jumlah & 367463 & 3597815 & \\
\hline
\end{tabular}

Sumber: Hasil Analisis, 2018

\section{Komoditas Unggulan Subsektor Pertanian Tanaman} Hortikultura Buah

Berdasarkan analisis Location Question ( $L Q)$ dan Shift Share (SS) terdapat beberapa komoditas yang menjadi unggulan Kecamatan Samigaluh yaitu komoditas buah duku/langsat, jeruk Siam, salak dan melinjo. Hal tersebut karena masing-masing dari komoditas tersebut memiliki nilai LQ > 1 dan nilai SS yang bernilai positif $(+)$ yang artinya komoditas tersebut mampu mencukupi kebututuhan di kecamatan Samigaluh dan memiliki pertumbuhan yang cepat sehingga mampu memicu pertumbuhan tanaman buah di kecamatan tersebut. TABEL 7

KOMODITAS UNGGULAN SUBSEKTOR PERTANIAN TANAMAN HORTIKULTURA

\begin{tabular}{|l|c|r|r|}
\hline \multirow{2}{*}{ Jenis Komoditas } & LQ & SS & Kesimpulan \\
\hline Alpokat & 3.144616 & -1984.16474 & Tidak unggul \\
\hline Mangga & 0.480122 & -1825.962967 & Tidak unggul \\
\hline Rambutan & 1.303624 & -1692.093248 & Tidak unggul \\
\hline Duku / Langsat & 7.065406 & 356.7376543 & Unggulan \\
\hline JerukBesar & 5.615967 & -128.1691729 & Tidak unggul \\
\hline Jeruk Siam & 1.226162 & 102.1792453 & Unggulan \\
\hline Sirsak & 0.226909 & 6.493117409 & Tidak unggul \\
\hline Durian & 0.959544 & 199.1293007 & Tidak unggul \\
\hline Jambu & 0.139982 & 178.4045715 & Tidak unggul \\
\hline Sukun & 1.465013 & -39.31717346 & Tidak unggul \\
\hline Sawo & 0.899452 & 40.87408185 & Tidak unggul \\
\hline
\end{tabular}




\begin{tabular}{|l|c|r|r|}
\hline Jenis Komoditas & LQ & \multicolumn{1}{|c|}{ SS } & Kesimpulan \\
\hline Pepaya & 1.066543 & -874.5194473 & Tidak unggul \\
\hline Pisang & 0.310558 & 349.7303178 & Tidak unggul \\
\hline Nanas & 0.394469 & -35.04690235 & Tidak unggul \\
\hline Salak & 2.647328 & 2997.641915 & Unggulan \\
\hline Nangka & 1.160606 & -883.8628142 & Tidak unggul \\
\hline Melinjo & 1.355858 & 155.3171572 & Unggulan \\
\hline Petai & 2.078221 & -1496.591079 & Tidak unggul \\
\hline
\end{tabular}

Sumber: Hasil Analisis, 2018

\section{Subsektor Pertanian Tanaman Obat}

Hasil Analisis Location Question (LQ) Subsektor Pertanian Tanaman Hortikultura Obat

Pada tabel di bawahdapat dilihat komoditas tanaman obat yang memiliki nilai LQ>1, yaitu sebanyak 2 komoditas. Komoditas tersebut yaitu jahe dan mengkudu, dimana jahe memiliki nilai LQ sebesar 1,009 dan mengkudu sebesar 4, 51. Hal ini menunjukan bahwa hasil komoditas dari buah-buahan tersebut dapat mencukupi kebutuhan di Kecamatan Samigaluh dan di wilayah lainnya. Sedangkan untuk komoditas yang memiliki nilai $\mathrm{LQ}<1$, yaitu sebanyak 3 komoditas. Komoditas tersebut yaitu Laos, kencur dan kunyit, dimana Laos memiliki nilai LQ sebesar 0, 24, komoditas kencur sebesar 0, 15 dan komoditas kunyit sebesar 0,45 . Hal itu menunjukkan bahwa komoditas tersebut belum mampu untuk mencukupi kebutuhan di kecamatan samigaluh dan wilayah lain.

TABEL 8

HASIL ANALISIS LOCATION QUESTION (LQ) SUBSEKTOR PERTANIAN TANAMAN HORTIKULTURA

$$
\text { OBAT }
$$

\begin{tabular}{|l|r|r|c|}
\hline \multirow{2}{*}{$\begin{array}{c}\text { Jenis } \\
\text { Komoditas }\end{array}$} & \multicolumn{2}{|c|}{ Produksi (ton) } & \multirow{2}{*}{ LQ } \\
\cline { 2 - 3 } & $\begin{array}{c}\text { Kecamatan } \\
\text { Samigaluh }\end{array}$ & $\begin{array}{c}\text { Kabupaten } \\
\text { Kulon Progo }\end{array}$ & \\
\hline Jahe & 1572146 & 13325459 & 1.00917 \\
\hline Laos & 162281 & 5712143 & 0.24301 \\
\hline Kencur & 159237 & 8866561 & 0.15362 \\
\hline Kunyit & 737511 & 13990886 & 0.4509 \\
\hline Mengkudu & 2912351 & 5522525 & 4.5109 \\
\hline Jumlah & 5543526 & 47417574 & \\
\hline
\end{tabular}

Sumber: Hasil Analisis, 2018

Hasil Analisis Shift Share (SS) Subsektor Pertanian Tanaman Hortikultura Obat

Berdasarkan hasil analisis Shift Share (SS) subsector pertanian tanaman hortikulturan obat, diketahui bahwa terdapat beberapa komoditas yang memiliki nilai Shift Share positif (+) yaitu komoditas kencur, kunyit dan mengkudu. Komoditas kencur memiliki nilai SS sebesar 15,144 , komoditas kunyit sebesar 92,645 , dan komoditas mengkudu sebesar 13,024. Hal itu menunjukkan bahwa komoditas-komoditas tersebut memiliki pertumbuhan yang cepat sehingga dapat memacu pertumbuhan komoditas tanaman obat lainnya.

Namun disisi lain masih terdapat beberapa komoditas yang memiliki nilai perhitungan Shift Share yang bernilai negatif (-) yaitu komoditas jahe dan laos. Komoditas jahe memiliki nilai SS sebesar -264430 dan Laos sebesar -23650. Dengan demikian dapat disimpulkan bahwa perkembangan dari komoditas tersebut tidak dapat memicu pertumbuhan komoditas tanaman obat yang lainnya karena memiliki pertumbuhan yang lambat.

TABEL 9

HASIL ANALISIS SHIFT SHARE (SS)

SUBSEKTOR PERTANIAN TANAMAN HORTIKULTURA OBAT

\begin{tabular}{|l|r|r|r|}
\hline \multirow{2}{*}{$\begin{array}{c}\text { Jenis } \\
\text { Komoditas }\end{array}$} & \multicolumn{2}{|c|}{ Produksi (ton) } & \multirow{2}{*}{ SS } \\
\cline { 2 - 3 } & $\begin{array}{c}\text { Kecamatan } \\
\text { Samigaluh }\end{array}$ & $\begin{array}{c}\text { Kabupaten } \\
\text { Kulon Progo }\end{array}$ & \\
\hline Jahe & 1572146 & 13325459 & -264430 \\
\hline Laos & 162281 & 5712143 & -23650 \\
\hline Kencur & 159237 & 8866561 & 15144.54 \\
\hline Kunyit & 737511 & 13990886 & 92645.27 \\
\hline Mengkudu & 2912351 & 5522525 & 13024.13 \\
\hline Jumlah & 5543526 & 47417574 & \\
\hline
\end{tabular}

Sumber: Hasil Analisis, 2018

Komoditas Unggulan Subsektor Pertanian Tanaman Obat

Berdasarkan analisis Location Question (LQ) dan Shift Share $(S S)$ terdapat beberapa komoditas yang menjadi unggulan Kecamatan Samigaluh yaitu komoditas mengkudu. Hal itu karena komoditas tersebut memiliki nilai LQ>1 yaitu sebesar 4,51 dan nilai SS yang bernilai positif (+) yaitu sebesar 13,024 yang artinya komoditas tersebut mampu mencukupi kebututuhan di Kecamatan Samigaluh dan mampu memicu pertumbuhan tanaman obat di kecamatan tersebut.

TABEL 10

KOMODITAS UNGGULAN SUBSEKTOR PERTANIAN TANAMAN OBAT

\begin{tabular}{|l|r|r|r|}
\hline \multicolumn{1}{|c|}{$\begin{array}{c}\text { Jenis } \\
\text { Komoditas }\end{array}$} & \multicolumn{1}{c|}{ LQ } & \multicolumn{1}{c|}{ SS } & Kesimpulan \\
\hline Jahe & 1.009169 & -264430 & Tidak unggul \\
\hline Laos & 0.243009 & -23650 & Tidak unggul \\
\hline Kencur & 0.153618 & 15144.54 & Tidak unggul \\
\hline Kunyit & 0.450896 & 92645.27 & Tidak unggul \\
\hline Mengkudu & 4.510859 & 13024.13 & Unggulan \\
\hline
\end{tabular}

Sumber: Hasil Analisis, 2018

\section{Subsektor Perkebunan}

Hasil Analisis Location Question (LQ) Subsektor Perkebunan

Berdasarkan hasil analisis Location Question (LQ) yang dilakukan, diketahui bahwa komoditas tanaman perkebunan hampir semua komoditas memiliki nilai 
LQ > 1 . Komoditas yang memiliki nilai LQ > 1 , yaitu sebanyak 5 komoditas. Komoditas tersebut yaitu kakao, kopi, cengkeh, teh dan nilam, dimana kakao memiliki nilai LQ sebesar 1.14, kopi sebesar 5,98, cengkeh sebesar 5,20, teh sebesar 6,61 dan tanaman nilam sebesar 9,44. Hal ini menunjukan bahwa hasil komoditas dari tanaman perkebunan tersebut dapat mencukupi kebutuhan di Kecamatan Samigaluh dan di wilayah lainnya.

Sedangkan untuk komoditas tanaman kelapa memiliki nilai $\mathrm{LQ}<1$, dimana sebesar 0 , 43. Hal itu menunjukkan bahwa komoditas tersebut belum mampu untuk mencukupi kebutuhan di Kecamatan Samigaluh dan wilayah lain.

TABEL 11

HASIL ANALISIS LOCATION QUESTION (LQ) SUBSEKTOR PERKEBUNAN

\begin{tabular}{|l|r|r|r|}
\hline \multirow{2}{*}{ Jenis Komoditas } & \multicolumn{2}{|c|}{ Produksi (ton) } & \multirow{2}{*}{ LQ } \\
\cline { 2 - 3 } & $\begin{array}{c}\text { Kecamatan } \\
\text { Samigaluh }\end{array}$ & $\begin{array}{c}\text { Kabupaten } \\
\text { Kulon Progo }\end{array}$ & \\
\hline Tanaman Kakao & 1702.01 & 17116.58 & 1.149 \\
\hline Tanaman Kopi & 3308.82 & 6384.8 & 5.988 \\
\hline Tanaman Kelapa & 6486.88 & 171486.11 & 0.437 \\
\hline Tanaman Cengkeh & 1536.76 & 3408.47 & 5.21 \\
\hline Tanaman Teh & 2050.92 & 3579.79 & 6.62 \\
\hline Tanaman Nilam & 2677.81 & 3276.22 & 9.444 \\
\hline Jumlah & 17763.2 & 205251.97 & \\
\hline
\end{tabular}

Sumber: Hasil Analisis, 2018

Hasil Analisis Shift Share (SS) Subsektor Perkebunan Pada tabel di bawah terdapat beberapa komoditas yang memiliki nilai Shift Share positif (+) yaitu komoditas tanaman kakao, cengkeh dan nilam. Dimana tanaman kakao memiliki nilai sebesar 304.26, komoditas cengkeh sebesar 242.08 dan komoditas nilam sebesar 7.17. Hal itu menunjukkan bahwa komoditas tersebut memiliki pertumbuhan yang cepat sehingga dapat memacu pertumbuhan tanaman perkebunan lainnya.

Namun disisi lain masih terdapat beberapa komoditas yang memiliki nilai perhitungan Shift Share yang bernilai negatif (-) yaitu komoditas kopi, kelapa dan teh. Dimana komoditas kopi memiliki nilai SS sebesar -169.46, kelapa sebesar -2727.01 dan teh sebesar -31.98. Sehingga perkembangan dari komoditas tersebut tidak dapat memicu pertumbuhan pada sektor tanaman buah karena memiliki pertumbuhan yang lambat.

TABEL 12

HASIL ANALISIS SHIFT SHARE (SS) SUBSEKTOR PERKEBUNAN

\begin{tabular}{|l|r|r|c|}
\hline \multirow{2}{*}{ Jenis Komoditas } & \multicolumn{2}{|c|}{ Produksi (ton) } & \multirow{2}{*}{ SS } \\
\cline { 2 - 3 } & $\begin{array}{c}\text { Kecamatan } \\
\text { Samigaluh }\end{array}$ & $\begin{array}{c}\text { Kabupaten } \\
\text { KulonProgo }\end{array}$ & \\
\hline Tanaman Kakao & 1702.01 & 17116.58 & 304.266 \\
\hline Tanaman Kopi & 3308.82 & 6384.8 & -169.47 \\
\hline
\end{tabular}

\begin{tabular}{|l|r|r|r|}
\hline \multirow{2}{*}{ Jenis Komoditas } & \multicolumn{2}{|c|}{ Produksi (ton) } & \multirow{2}{*}{ SS } \\
\cline { 2 - 3 } & $\begin{array}{c}\text { Kecamatan } \\
\text { Samigaluh }\end{array}$ & $\begin{array}{c}\text { Kabupaten } \\
\text { KulonProgo }\end{array}$ & \\
\hline Tanaman Kelapa & 6486.88 & 171486.11 & -2727 \\
\hline Tanaman Cengkeh & 1536.76 & 3408.47 & 242.084 \\
\hline Tanaman Teh & 2050.92 & 3579.79 & -31.985 \\
\hline Tanaman Nilam & 2677.81 & 3276.22 & 7.1761 \\
\hline Jumlah & 17763.2 & 205251.97 & \\
\hline
\end{tabular}

Sumber: Hasil Analisis, 2018

Komoditas Unggulan Subsektor Perkebunan

Berdasarkan analisis Location Question (LQ) dan Shift Share (SS) diketahui bahwa terdapat beberapa komoditas yang menjadi unggulan Kecamatan Samigaluh yaitu komoditas kakao, cengkeh dan nilam. Hal itu karena komoditas tersebut memiliki nilai LQ > 1, dimana komoditas kakao memiliki nilai sebesar 1.14, komoditas cengkeh sebesar 5, 20 dan sebesar 9, 44 untuk komoditas nilam. Sedangkan jika dilihat dari nilai Shift Share ketiga komoditas tersebut juga memiliki nilai positif (+) dimana komoditas kakao memiliki nilai sebesar 304.26, komoditas cengkeh memiliki nilai sebesar 242.08 dan komoditas nilam memiliki nilai sebesar 7.17, yang artinya komoditas tersebut mampu mencukupi kebututuhan di Kecamatan Samigaluh dan mampu memicu pertumbuhan tanaman perkebunan di kecamatan tersebut.

TABEL 13

KOMODITAS UNGGULAN

SUBSEKTOR PERKEBUNAN

\begin{tabular}{|l|r|r|r|}
\hline \multicolumn{1}{|c|}{ Jenis Komoditas } & \multicolumn{1}{c|}{ LQ } & \multicolumn{1}{c|}{ SS } & Kesimpulan \\
\hline Tanaman Kakao & 1.14898 & 304.266 & Unggulan \\
\hline Tanaman Kopi & 5.98814 & -169.47 & Tidak unggul \\
\hline Tanaman Kelapa & 0.43709 & -2727 & Tidak unggul \\
\hline Tanaman Cengkeh & 5.2097 & 242.084 & Unggulan \\
\hline Tanaman Teh & 6.61999 & -31.985 & Tidak unggul \\
\hline Tanaman Nilam & 9.44437 & 7.17611 & Unggulan \\
\hline
\end{tabular}

Sumber: Hasil Analisis, 2018

\section{Subsektor Peternakan}

Hasil Analisis Location Question (LQ) Subsektor Peternakan

Berdasarkan hasil analisis Location Question (LQ) pada subsector peternakan, diketahui bahwa komoditas hewan ternak yang memiliki nilai LQ > 1 , yaitu sebanyak 4 komoditas. Komoditas tersebut yaitu kerbau, kambing, domba dan kampung/buras, dimana kerbau memiliki nilai LQ sebesar 1,01, kambing sebesar 1,49, domba sebesar 1,28 dan kampung/buras sebesar 1,14. Hal ini menunjukan bahwa hasil komoditas hewan ternak tersebut dapat mencukupi kebutuhan di Kecamatan Samigaluh dan di wilayah lainnya.

167 | Jurnal Akuntansi, Ekonomi dan Manajemen Bisnis | Vol. 7 No.2, December 2019, 160-169 | E-ISSN: 2548-9836 
Sedangkan untuk komoditas yang memiliki nilai LQ $<1$, yaitu sebanyak 3 komoditas. Komoditas tersebut yaitu sapi, itik dan kelinci, dimana sapi memiliki nilai LQ sebesar 0, 49, komoditas itik sebesar 0, 09 dan komoditas kelinci sebesar 0, 60. Hal itu menunjukkan bahwa komoditas tersebut belum mampu untuk mencukupi kebutuhan di Kecamatan Samigaluh dan wilayah lain.

TABEL 14

HASIL ANALISIS LOCATION QUESTION (LQ) SUBSEKTOR PETERNAKAN

\begin{tabular}{|c|c|c|c|}
\hline \multirow{2}{*}{$\begin{array}{c}\text { Jenis } \\
\text { Komoditas }\end{array}$} & \multicolumn{2}{|c|}{ Produksi (ton) } & \multirow[b]{2}{*}{ LQ } \\
\hline & $\begin{array}{l}\text { Kecamatan } \\
\text { Samigaluh }\end{array}$ & $\begin{array}{c}\text { Kabupaten } \\
\text { Kulon Progo }\end{array}$ & \\
\hline Sapi & 13356 & 315353 & 0.4003 \\
\hline Kerbau & 65 & 603 & 1.0189 \\
\hline Kambing & 80750 & 510238 & 1.4959 \\
\hline Domba & 17674 & 129617 & 1.2888 \\
\hline $\begin{array}{l}\text { Kampung/ } \\
\text { Buras }\end{array}$ & 569390 & 4698265 & 1.1455 \\
\hline Itik & 7785 & 815554 & 0.0902 \\
\hline Kelinci & 6878 & 108079 & 0.6015 \\
\hline Jumlah & 695898 & 6577709 & \\
\hline
\end{tabular}

Sumber: Hasil Analisis, 2018

Hasil Analisis Shift Share (SS) Subsektor Peternakan Beradasarkan hasil analisis Shift Share (SS) pada subsector peternakan, diketahui bahwa terdapat beberapa komoditas yang memiliki nilai Shift Share positif (+) yaitu sapi, kambing, itik dan kelinci.Dimana sapi memiliki nilai sebesar 288,29; komoditas kambing sebesar 26,18; komoditas itik sebesar 105,94; dan kelinci sebesar 87,08. Hal itu menunjukkan bahwa komoditas tersebut memiliki pertumbuhan yang cepat sehingga dapat memacu pertumbuhan hewan ternak lainnya.

Namun disisi lain, masih terdapat beberapa komoditas yang memiliki nilai perhitungan Shift Share yang bernilai negatif (-) yaitu komoditas kerbau, domba dan kampung/buras. Dimana komoditas kerbau memiliki nilai SS sebesar -12.94, domba sebesar -964.27 dan kampung/buras sebesar 4518.65. Sehingga perkembangan dari komoditas tersebut tidak dapat memicu pertumbuhan pada sektor tanaman buah karena memiliki pertumbuhan yang lambat.

TABEL 15

HASIL ANALISIS SHIFT SHARE (SS) SUBSEKTOR PETERNAKAN

\begin{tabular}{|l|r|r|c|}
\hline \multirow{2}{*}{$\begin{array}{c}\text { Jenis } \\
\text { Komoditas }\end{array}$} & \multicolumn{2}{|c|}{ PUBSEKTOR PETERNAKA (ton) } & \multirow{2}{*}{ SS } \\
\cline { 2 - 3 } & $\begin{array}{c}\text { Kecamatan } \\
\text { Samigaluh }\end{array}$ & $\begin{array}{c}\text { Kabupaten Kulon } \\
\text { Progo }\end{array}$ & \\
\hline Sapi & 13356 & 315353 & 288.29 \\
\hline Kerbau & 65 & 603 & -12.944 \\
\hline Kambing & 80750 & 510238 & 26.1836 \\
\hline
\end{tabular}

\begin{tabular}{|c|c|c|c|}
\hline \multirow{2}{*}{$\begin{array}{c}\text { Jenis } \\
\text { Komoditas }\end{array}$} & \multicolumn{2}{|c|}{ Produksi (ton) } & \multirow{2}{*}{ SS } \\
\hline & $\begin{array}{l}\text { Kecamatan } \\
\text { Samigaluh }\end{array}$ & $\begin{array}{c}\text { Kabupaten Kulon } \\
\text { Progo }\end{array}$ & \\
\hline Domba & 17674 & 129617 & -964.27 \\
\hline $\begin{array}{l}\text { Kampung/ } \\
\text { Buras }\end{array}$ & 569390 & 4698265 & -4518.7 \\
\hline Itik & 7785 & 815554 & 105.95 \\
\hline Kelinci & 6878 & 108079 & 87.086 \\
\hline Jumlah & 695898 & 6577709 & \\
\hline
\end{tabular}

Sumber: Hasil Analisis, 2018

\section{Komoditas Unggulan Subsektor Peternakan}

Berdasarkan analisis Location Question (LQ) dan Shift Share (SS) komoditas subsector peternakan yang menjadi unggulan Kecamatan Samigaluh yaitu kambing. Hal itu karena komoditas tersebut memiliki nilai LQ > 1 yaitu sebesar 1,49 dan nilai SS yang bernilai positif (+) yaitu sebesar 26,18 yang artinya komoditas tersebut mampu mencukupi kebutuhan di Kecamatan Samigaluh dan mampu memicu pertumbuhan komoditas hewan ternak di kecamatan tersebut.

TABEL 16

KOMODITAS UNGGULAN SUBSEKTOR PETERNAKAN

\begin{tabular}{|l|r|r|r|}
\hline \multicolumn{1}{|c|}{ Jenis Komoditas } & \multicolumn{1}{c|}{ LQ } & \multicolumn{1}{c|}{ SS } & Kesimpulan \\
\hline Sapi & 0.400321 & 288.294 & Tidak unggul \\
\hline Kerbau & 1.018885 & -12.9435 & Tidak unggul \\
\hline Kambing & 1.495887 & 26.18364 & Unggulan \\
\hline Domba & 1.288849 & -964.272 & Tidak unggul \\
\hline Kampung/Buras & 1.145517 & -4518.65 & Tidak unggul \\
\hline Itik & 0.090227 & 105.9468 & Tidak unggul \\
\hline Kelinci & 0.60152 & 87.08642 & Tidak unggul \\
\hline
\end{tabular}

Sumber: Hasil Analisis, 2018

\section{KESIMPULAN}

Kesimpulan yang dapat diambil dari penelitian ini adalah Kecamatan Samigaluh memiliki cukup banyak komoditas unggulan antara lain:

a. Sub-sector pertanian tanaman pangan: padi sawah/ladang.

b. Sub-sektor pertanian tanaman hortikultura buah: duku/langsat, jeruk Siam, salak, dan melinjo.

c. Sub-sektor pertanian tanaman hortikultura obat: mengkudu.

d. Sub-sektor pertanian tanaman perkebunan: tanaman kakao, cengkeh, dan nilam.

e. Sub-sektor peternakan: kambing.

\section{SARAN}

Saran yang dapat diberikan dari penelitian ini adalah: 1. Diversifikasi komoditas-komoditas unggulan yang dimiliki oleh Kecamatan Samigaluh sehingga bisa memberikan nilai tambah yang pada tahap 
selanjutnya bisa meningkatkan pendapatan penduduk setempat. Misalnya komoditas kambing diolah susunya (pasteurisasi) sehingga akan lebih tahan lama dan nilai jualnya semakin tinggi.

2. Pemberian pelatihan pengolahan komoditas komoditas unggulan untuk penduduk setempat bekerja sama dengan pihak lain (misal UGM melalui kegiatan pengabdian).

\section{DAFTAR PUSTAKA}

[1] Kareza dan Muta'ali, Variasi Tingkat Perekonomian antar Kecamatan di Kabupaten Kulon Progo. Jurnal Bumi Indonesia, Vol. 3, No. 4, 2014.

[2] Kuncoro Mudrajad, Otonomi Daerah: Menuju Era Baru Pembangunan Daerah, Erlangga, Jakarta, 2014.

[3] Glasson John, Pengantar Perencanaan Regional, LPFE Universitas Indonesia, Jakarta, 1997.

[4] Tarigan Robinson, Ekonomi Regional: Teori dan Aplikasi, PT. Bumi Aksara, Jakarta, 2007.

[5] Kadariah, Ekonomi Perencanaan, Lembaga Penerbit FE-UI, Jakarta, 1985

[6] Tarigan Robinson, Ekonomi Regional: Teori dan Aplikasi Edisi Revisi, Bumi Aksara, Jakarta, 2005.

[7] Saputra Awan Arga dan Ayundyah Kesumawati, Analisis Potensi Kecamatan Berbasis Komoditas Pertanian dalam Pembangunan Wilayah di Kabupaten Sleman, Seminar Nasional Matematika dan Pendidikan Matematika UNY, 2016.

[8] Bendavid-val, Avrom, Regional and Local Economic Analysis for Practitioners, Prager Publisher, New York, 1991.

[9] Ron Hood, Economic Analysis: A Location Quotient, Principal Sun Region Associates, Inc. 1998

[10]Rahayu Puji dan Ardy Maulidy Navastara, Penentuan Wilayah Potensial Komoditas Jagung di Kabupaten Kediri, Jurnal Teknik ITS, Vol. 3 No. 1,2014 